EPJ Web of Conferences 12, 01003 (2011)

DOI: $10.1051 /$ epjconf/20111201003

(C) Owned by the authors, published by EDP Sciences, 2011

\title{
Ageing management program for the Spanish low and intermediate level waste disposal and spent fuel and high-level waste centralised storage facilities
}

\author{
P. Zuloaga ${ }^{1}$, M. Ordoñez ${ }^{1}$, C. Andrade ${ }^{2}$ and M. Castellote ${ }^{2}$ \\ ${ }^{1}$ ENRESA, Emilio Vargas 7, 28043 Madrid, Spain \\ 2 Instituto Eduardo Torroja, Serrano Galvache sn, 28043 Madrid, Spain
}

\begin{abstract}
The generic design of the centralised spent fuel storage facility was approved by the Spanish Safety Authority in 2006. The planned operational life is 60 years, while the design service life is 100 years. Durability studies and surveillance of the behaviour have been considered from the initial design steps, taking into account the accessibility limitations and temperatures involved. The paper presents an overview of the ageing management program set in support of the Performance Assessment and Safety Review of El Cabril low and intermediate level waste (LILW) disposal facility. Based on the experience gained for LILW, ENRESA has developed a preliminary definition of the Ageing Management Plan for the Centralised Interim Storage Facility of spent Fuel and High Level Waste (HLW), which addresses the behaviour of spent fuel, its retrievability, the confinement system and the reinforced concrete structure. It includes tests plans and surveillance design considerations, based on the El Cabril LILW disposal facility.
\end{abstract}

\section{INTRODUCTION}

Spain has eight power reactors in operation with a total capacity of $8.3 \mathrm{GWe}$. All power plants fuel ponds have been re-racked to increase their storage capacity. Furthermore, two nuclear power plants are closed down and are in different ages of the decommissioning process. Vandellós I gas cooled reactor is now in latency period after finishing stage 1 of the decommissioning operations (all the station, except the reactor vessel, which remains sealed in safe storage condition). Its spent fuel was sent to France for reprocessing, and, eventually, some high and medium-level waste should be sent back to Spain. The Jose Cabrera PWR is being dismantled, its pool was defueled in 2009 and its spent fuel (300 t of uranium) is dry-stored in multipurpose canisters on site. The total planned spent fuel inventory in the country is around 6700 tones of uranium. Moreover, some 69 canisters of high-level vitrified waste and some 650 cubic meters of long-lived medium-level waste packages of different types should also be stored in the same facility. Low and Intermediate Level Waste (LILW) are defined as the ones complying with the El Cabril disposal facility, in operation since 1992.

The Spanish national radioactive waste and spent fuel management policy is set by the Government in a cabinet-approved General Radioactive Waste Plan. The current $6^{\text {th }}$ Plan [1] gives priority to a centralised storage facility for spent fuel and high-level waste, in agreement with parliamentary recommendations on different occasions. The process for site selection of the Spanish Spent Fuel and High-level Waste Centralised Storage Facility (Almacén Temporal Centralizado - ATC) was launched in 2009 [2], based on a volunteer community scheme. An ad-hoc inter-ministerial commission presented its report on the site selection in September 2010. The site designation is now on the hands of the Cabinet. Together with the storage facility, the ATC project also considers the construction of a Technological Research Centre supporting ENRESA's R\&D Plan on spent fuel and radioactive waste management.

This is an Open Access article distributed under the terms of the Creative Commons Attribution-Noncommercial License 3.0, which permits unrestricted use, distribution, and reproduction in any noncommercial medium, provided the original work is properly cited. 


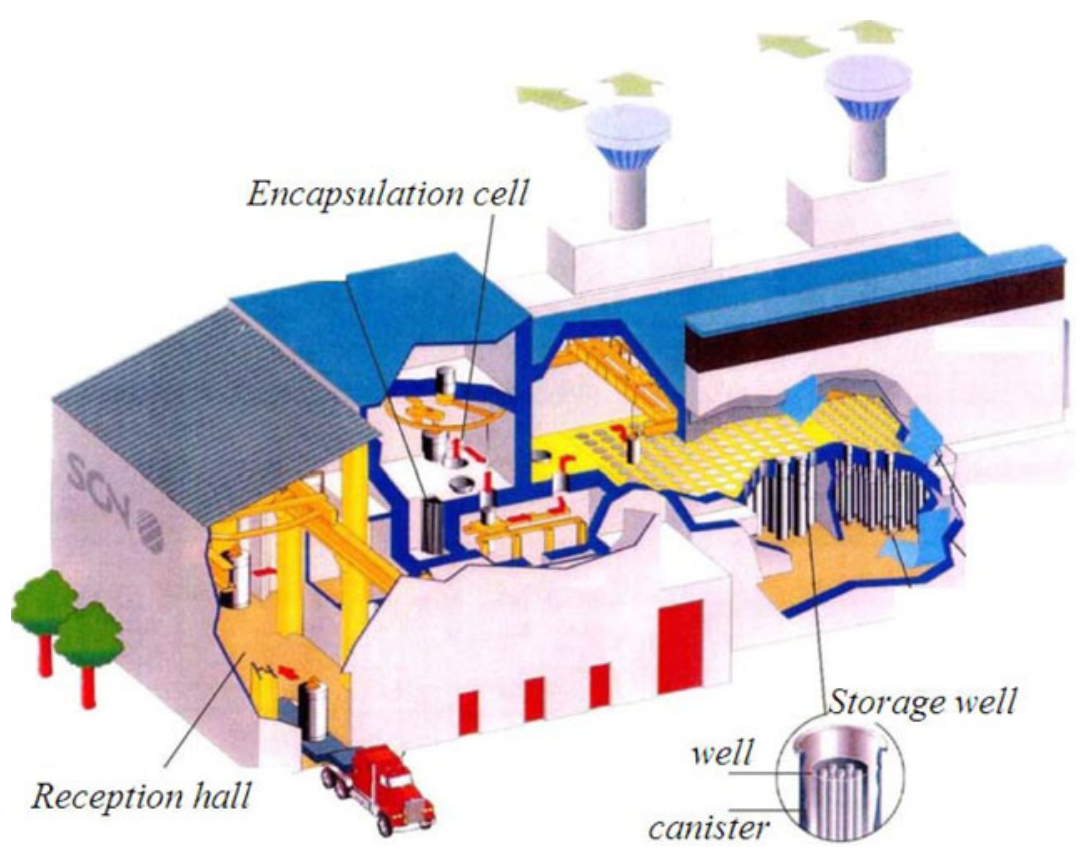

Figure 1. Conceptual design of the Spanish SF and HLW Centralised Storage Facility.

This research centre will contain, among others, a spent fuel and radioactive waste laboratory intended for post-irradiation characterisation of spent fuel and irradiated materials to support the performance assessment of the different long-term management options, including storage for more prolonged periods and final disposal conditions.

ENRESA is the Spanish organization responsible for the long-term management of all categories of radioactive waste and spent nuclear fuel and for carrying our decommissioning of redundant nuclear installations. It is thus responsible for developing, constructing and operating the centralised storage facility and is now focused on preparing the site characterisation and design, in order to license and build the facility and the associated research centre.

A generic design of the storage facility, based on vault type storage, was approved by the Spanish Safety Authority, Consejo de Seguridad Nuclear (CSN), in 2006 [3]. Figure 1 shows a schematic diagram of the facility. Spent fuel is transferred to a canister in a hot-cell. The stainless steel canister is vacuum dried, backfilled with helium and double sealed. The canister is then transferred to a stainless steel storage well (two canisters per well). The gap between the canister and the well is then backfilled with nitrogen. The storage well has a double wall; the annulus formed provides a circulation path for the cooling air, which will not be in direct contact with the canister. Cooling is ensured by natural convection induced by the residual heat generated by the spent fuel or high level waste.

The planned operational life for the storage facility shown in Figure 1 is 60 years and the design service life objective is 100 years [4], but, when talking of periods of decades, assumptions of longer storage periods should be considered. Service life meaning has a twofold focus. On the one hand, safety is the paramount objective: to maintain all safety functions such as confinement, shielding and integrity to allow for physical protection and natural draft cooling. On the other hand, future decision-making on spent fuel management options must not be jeopardized and the possibility to recover spent fuel assemblies in a good state must be kept.

A prime concern is the durability of the facility with minimum maintenance, especially in the non accessible parts. Durability studies for longer storage periods and surveillance of the structure behaviour have to be considered during the initial steps of the basic design and during the detailed 
design development, especially when considering the strong accessibility limitations inherent to the facility and the relatively high temperatures involved. A prime concern is the durability of the facility with minimum maintenance. A facility of this type is designed to provide retrievability and reversibility: spent fuel canisters can be easily recovered from the storage wells, and reopened in the existing hot-cell. Spent fuel assemblies can then be taken out, inspected and re-canistered. A complete vault has been planned as a reserve, in order to allow a vault to be emptied in case of necessity and to permit entrance, inspection and repair of the evacuated vault. Naturally, this cannot be taken as the basis for routine surveillance and maintenance activities and it would only be considered in exceptional circumstances.

For the purpose of defining the ageing management plan, the facility can be divided to three main elements:

- The fuel assemblies that may need to be taken from the canisters in the future;

- The confinement system, formed by the stainless steel canisters and the stainless steel storage wells;

- The thick walled reinforced concrete structure providing support, shielding and physical protection.

The preliminary ageing management plan for the concrete structures of the ATC is based on the durability and surveillance works developed over many years by ENRESA, with the guidance and assistance of Instituto Eduardo Torroja [5], in support of the safety review and performance assessment improvement of the Spanish Low and Intermediate Level Waste Disposal Facility of El Cabril, which has been in operation since 1992.

The objective of this paper is to briefly describe the ageing management program set for the El Cabril LILW disposal facility as a key aspect of the performance assessment enhancement plans. This program is also an important reference for the preliminary definition of the ageing management program of the ATC facility. The paper also describes the main aspects of this ATC ageing management program in its three main components: the spent fuel assemblies, the confinement system and the concrete structure. The paper

\section{AGEING MANAGEMENT PROGRAM FOR EL CABRIL LILW DISPOSAL FACILITY}

The basic criteria adopted for surface disposal of LILW include a design objective of 300 years service life for the engineered barriers and low maintenance requirements. Since isolation of radionuclides is the main function of the engineered barriers, there is no a clear definition of the limit states: strictly, they should be interpreted in terms of dose restriction (e.g. $0.1 \mathrm{mSv} / \mathrm{y}$ to any individual of the critical group of the public) although, for practical reasons, service life is addressed in more conventional structural criteria. The durability required or such extended periods may make it necessary to speak about confidence building rather than on demonstration. Confidence may not be supported only by modelling but by showing robust solutions, together with a good knowledge of the degradation processes involved. This approach is presented to the stakeholders through a safety case, containing a performance assessment with simplified models using envelope assumptions. The goal of the program, in the operational phase of the facility, is to better understand all the potential processes, and confirm that the hypothesis adopted in the performance assessment are really envelope conditions, thus improving the long-term safety case and the knowledge of the existing margins.

The scope of the ageing management program includes four main components of the disposal system, namely, the concrete vaults, the concrete containers, the primary packages cementitious matrices and the cement grout backfilling the concrete containers.

Durability was a concern from the pre-operational phase of the facility project. A research program was launched in co-operation with Instituto Eduardo Torroja (IETCC-CSIC), initially oriented towards optimising the durability of the engineered barriers, taking into account all the potential degradation mechanisms. In a second step the goal was service life assessment: models, from simple models to more 
sophisticated ones, were developed to assess the service life of the barriers and characterisation of real samples was enhanced to obtain more data to verify those models. Since initial operation, the research and surveillance program included specimen follow-up from fabricated containers and real packages and from the construction of the vaults, stored in different conditions; measurement of permeability to gas of the covering and measurement of corrosion parameters (corrosion potential and velocity) in real vaults walls; and the construction of an instrumented pilot container, stored in conditions representative of the real disposal vaults. This pilot container has embedded 21 groups of electro-chemical sensors (corrosion potential and intensity, oxygen availability), strain gauges, resistivity, and temperature sensors

The current program is focused in supporting a continuous effort in performance assessment enhancement and the periodic safety review. This program consists of:

- Continuation of monitoring of the disposal vaults through gas permeability and corrosion parameters measurement every six months, on the last vault to be filled with waste, and through the installation of thermo-hygrometric instrumentation in two vaults: one in the outer surface, one in the interior surface and pile of waste containers, with the cables spread through the drainage port.

- Continuation of control tests (mechanical, sorption, porosimetry,) in a yearly basis.

- Continuation of the data collection at the instrumented pilot container test bed. It has been decided not to dismount the pilot container and update the data collection system.

- Enhanced characterisation of materials, paying attention to permeability, thermal properties, unsaturated permeability, distribution coefficients and retention curves, and concentration profiles to verify models.

- Durability tests, including leaching (surface and-flow through), chloride depassivation thresholds, sulphate resistance and sulphate affection thresholds, freeze and thaw, etc

- Modelling including thermo-hydro-mechanical models and connected reactive transport models to consider non isothermal conditions and capillary water absorption.

\section{MAIN GAPS ANALYSIS AND PREVIOUS RESEARCH FOR THE ATC AGEING MANAGEMENT PROGRAM DEFINITION}

In this type of installations, service life can be defined as the period during which the system can fulfil the design requirements of sub-criticality (basic maintenance of the geometry); confinement (double barrier); and shielding. Retrievability is also a prime requirement for a storage facility, where spent fuel has to be retrieved and transported outside for the next management step according to the option that could be selected (direct disposal, recycling, partioning and transmutation). Dry storage of spent fuel is well covered by regulations, which are based on storage periods of up to 60 to 100 years. Nevertheless, it should be recognized that the length of the storage period for decades presents uncertainties that make it advisable to consider even more extended periods in the analysis.

Thus, ageing management should consider the behaviour of fuel assemblies, in such aspects as potential embrittlement of high burn-up fuel and oxidation. It also should address the confinement system. The third main component is the reinforced concrete structure, where in addition to those features that may be considered similar to the above described LILW program, the presence of sections subject to higher temperatures require particular attention.

Some research work has been developed in the area of spent fuel assemblies' behaviour. Modelling of mechanical behaviour of cladding in dry storage and transportation conditions, revising and adapting FRAPCON-3 [6] is under way with assistance of CIEMAT. A number of research projects have been jointly launched in association with the Spanish Safety Regulator (CSN) and ENUSA Tecnologías Avanzadas to support design bases adoption and regulatory guidance in this field. These projects include cladding creep tests with the aim of determining creep laws in a number of irradiated cladding samples 
under temperature, stress, and hydride conditions (concentration and orientation) of interest under dry storage both for high-burn-up Zirlo and Zircaloy 2 cladding.

A project on cladding failure modes (also in co-operation with CSN and ENUSA) is being carried out by the Polytechnic University of Madrid (UPM). Exchange of information has been agreed with French Institute for Radiation Protection and Nuclear safety (IRSN) and Japanese Universities. The scope of this project contains: artificial hydride doping of fresh alloys using electrolytic techniques and thermal homogenization, fracture energy determination, failure modelling, and mechanical tests mainly ring compression to verify models.

\section{BEHAVIOUR OF SPENT FUEL ASSEMBLIES}

Spent fuel assemblies contain a variety of materials, and have been subjected to different burn-up conditions, including high burn-up fuel up to 60,000 MWd/tU. Rods are made of different zirconium alloys and are not considered as a barrier in the conceptual design of ATC. In fact, damaged fuel is handled in special containers that prevent materials dispersion but are not leak proof. Nevertheless, for retrievability sake, they should maintain basically the integrity. For reaching this goal the strategy is based on:

- Having an inert environment to prevent corrosion

- Limiting temperature of cladding through adequate cooling.

Spent fuel is stored in a dry helium atmosphere inside the storage canisters. Except for short periods during drying or design accidental conditions, temperatures are maintained below a $400^{\circ} \mathrm{C}$ threshold [7]. For spent Fuel burned up to more than $45,000 \mathrm{MWd} / \mathrm{tU}$, this $400^{\circ} \mathrm{C}$ limit is also adopted for short-term operations such as drying, in order to prevent reorientation of hydrides. In the ATC project, the maximum temperature in long-term storage conditions has been reduced to $380{ }^{\circ} \mathrm{C}$ to avoid controversies [8].

Once sealed in the canister, there is no possibility of monitoring the evolution of the fuel assembly inside the canister, and to verify the state, the canister has to be opened. The main process of loading canisters at the ATC facility includes a handling hot-cell. Besides, the research spent fuel and radioactive waste laboratory annex to the ATC complex provides means to a through examination and mechanical testing of irradiated fuel and other irradiated materials.

Before loading campaigns, a number of spent fuel assemblies would be selected as targets for surveillance of the long-term behaviour of spent fuel in dry-storage conditions. These selected assemblies will be characterized in detail, including inspection by high resolution colour TV, noble gas seeping, profilometry, and gamma spectrometry, as well as separation of one rod and post-irradiation examination of this rod at the laboratory. The remainder of the fuel assembly will be stored in the normal process, preferably at the centre of a vault, where higher temperatures can be expected. The number of fuel assemblies pre-selected for examination is limited to six (two low burn-up PWR; two high burn-up PWR; one BWR low burn-up; one BWR high burn-up), taking into account the complexity and cost of this characterisation. If there is not a technical specification or contractual provision forbidding filling up a canister with fuel from different power plants, they will be stored in only two different canisters. After 15 years for two PWR assemblies and 30 years for the other fuel assemblies, the canisters will be recovered from the storage wells and sent to the hot-cell. There, they will be opened and the fuel extracted and inspected at the hot-cell. One rod will be extracted from the fuel assembly and sent too the annex laboratory for PIE and mechanical testing of the rod material.

\section{BEHAVIOUR OF THE CONFINEMENT SYSTEM}

The canister and the storage wells provide the double barrier of the confinement system. The canister contains dry helium inside and the gap between the canister and the well is back-filled with nitrogen or argon. The gap is monitored for helium leaks. The stainless steel canister can be considered as in a 


\section{EPJ Web of Conferences}

very low aggressivity environment, while it is difficult to monitor its evolution, except for the abovementioned leak detection. Additional inspections require opening the storage wells lids. This is done using a shielded transfer device. If some corrosion test specimens can be left on the upper surface of the canister, made of the same material, the specimens could be taken away with the assistance of the transfer device (whose design should be reviewed). The preliminary proposal is to use such specimens and open one well every two years. Inspection of a real loaded canister appears to be more complex and may be connected to the surveillance of the spent fuel addressed in section 2, with two potential solutions:

- Completely unload the canister to the hot-cell storage rack; inspect the interiorwith cameras; after checking radiation levels allow ingress to the canisters' corridor for external inspection.

- Remotely inspect with cameras the interior in the upper part of the canister and position that has been emptied; and remotely inspect the outer part.

The storage well interior has an inert gas atmosphere, but the outer surface is in contact with the cooling air that circulates through the gap between the storage well and its sleeve. The cooling air is not conditioned in any form and could contain dust and humidity. All the potential sites studied are in rural, non-seaside areas and mild climate, showing no particular aggressiveness to the stainless steel well. As the cooling air rises, it warms up, but condensation or water drop deposition cannot be completely precluded in the lower part. No major risk is identified; however, surveillance is focused in this area. Being completely inaccessible due to radiation levels, robust instrumentation may be useful, giving allowance for the failure of a percentage of sensors. Temperature and corrosion velocity measurement in a number of wells (e.g. six per vault, with preference in the tubes near the air inlet) is considered.

\section{BEHAVIOUR OF ATC REINFORCED CONCRETE STRUCTURES}

From a structural standpoint the reinforced concrete vaults provides support to the confinement and handling systems. Being a robust structure with wall thicknesses of near 2 meters, it also gives protection against natural or man originated external risks, including resistance to earthquakes. Such a structure, with a careful design and material selection should not present any particular problem for a service life of some decades. Nevertheless, a number of strategic decisions on spent fuel management options should be made. A 60 years operational period has been assumed for the facility. However, the decision-making 'processes for long-term management of spent fuel and high-level waste is subject to uncertainties. On the other hand, temperatures of $90{ }^{\circ} \mathrm{C}$ in the bulk of some sections of the structure are not normal in general civil structures. For these reasons durability has to be an issue in designing those structures and an ageing management plan is a must.

The first step will be an identification of materials suitable in the areas around the selected site. Concrete designed with these materials will be subject to a testing program, which will basically consist of the following tests:

- Characterisation tests (slump and fluidity; setting time and hardening; shrinkage and creep; mechanical characterisation - compressive and tensile; total porosity, density and pore size distribution -MIP; $\mathrm{X}$ ray diffraction

- General aging tests at normal and elevated temperature (electrical resistivity; gas permeability; porosity)

- Water flow tests (water permeability; water absorption isotherms-retention curves; capillary absorption)

- Durability tests (freeze-thaw resistance; carbonation resistance)

- Chloride resistance tests (multi-regime method; integral test - service life) 


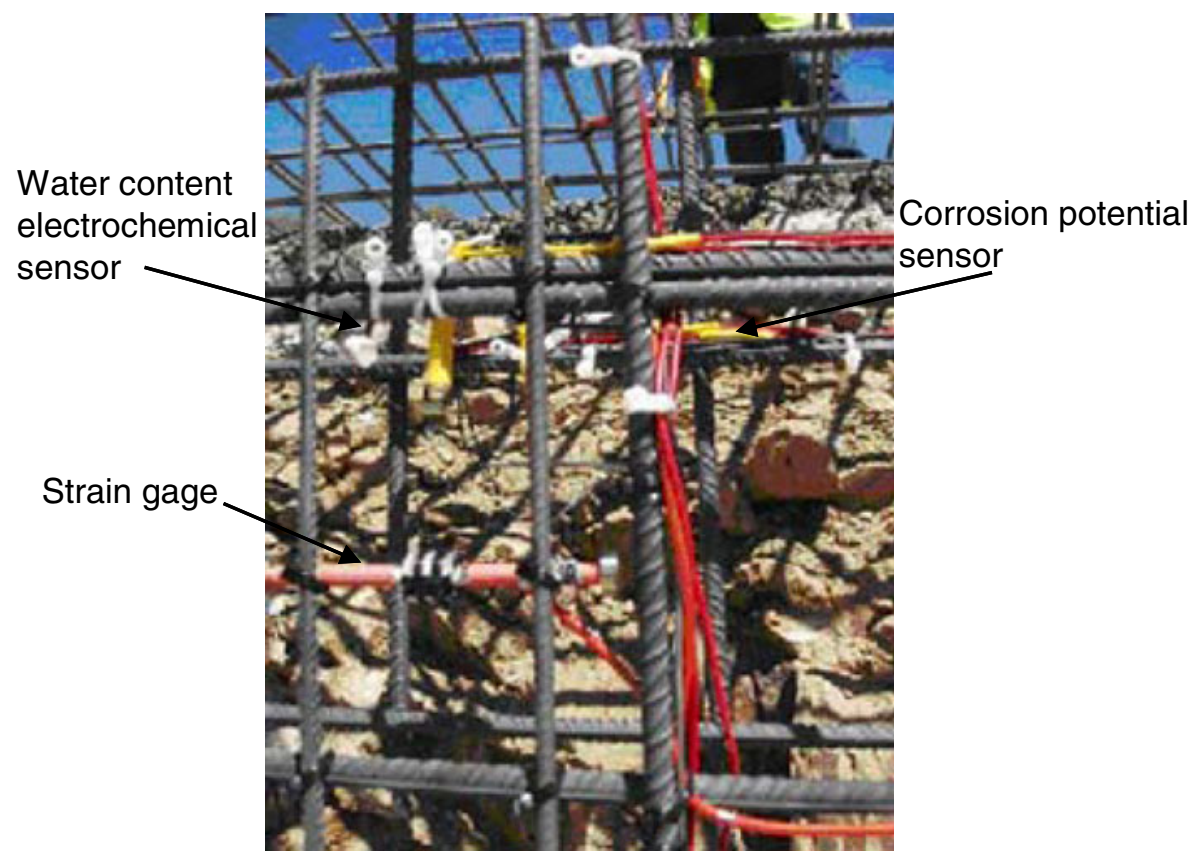

Figure 2. Group of electrochemical sensors embedded in a concrete structure representing a disposal vault in a test bed at El Cabril disposal facility site.

- Leaching tests (tank test; accelerated tests)

- Expansive attacks (silica aggregate reaction; sulphate expansion; accelerated transport; thaumasite verification).

The tests will be performed on the selection of materials and the design and characterisation of concrete, and afterwards during construction of the vaults.

The outer surfaces of the vaults are accessible and they can be periodically maintained, inspected, and tested. Among the tests, evolution of the surface permeability to gases may be verified and corrosion rate may be periodically measured with corrosion rate meters [9]. On the contrary, the inner surfaces are not accessible and cannot be inspected, and a number of simple electrochemical sensors have been proposed to monitor corrosion potential and velocity, polarization resistance, and resistivity in a way similar to the pilot container installed at the LILW disposal facility [10]. Nine groups of these sensors are initially considered in each vault to provide some redundancy because it will not be possible to replace them and to have information about different elements (e.g. upper warm parts vs. lower colder zones). Figure 2 shows a group of electrochemical sensors as installed in the concrete structure representing the disposal vault, as a part of the test bed for the final engineered cap evaluation at El Cabril LILW disposal facility.

To have information on the long-term evolution a test bed is foreseen consisting of three large reinforced concrete blocks ( $2 \mathrm{~m}$ cubes), stored in climatic chambers trying to reproduce the environmental conditions in the vaults. The blocks will have resistivity, temperature and capillary suction sensors embedded similar to those installed in the El Cabril cap test bed [11] shown in Figure 2. Additionally, these blocks will be inspected initially every year. After 15 and 30 years one of the blocks will be subject to destructive testing and analysis, leaving the third as a reference during the operation of the storage facility. In 15 years experience monitoring the instrumented pilot container at El Cabril, less than $10 \%$ of the sensors have failed. In the engineered cap test bed where new sensors have been 
installed; only one year of data collection is available. These tests will provide reliable information supporting the final decision of the sensor types installed in the ATC structure and in three test blocks foreseen for monitoring.

\section{CONCLUSIONS}

The ageing management program for the El Cabril LILW disposal facility provides a strong support to the performance assessment and safety case improvement effort.

The early definition of an ageing management plan for the Spanish spent fuel and HLW centralised storage facility will support the development of the design and licensing processes, taking into account the optimisation of the durability of the different components and the surveillance requirements from the very beginning, thus preventing the need of potential expensive modifications during construction or initial operations.

\section{References}

[1] Ministerio de Industria, Turismo y Comercio (Ministry of Industry, Tourism, and Commerce). Spain. $6^{\text {th }}$ General Radioactive Waste Plan. June 2006 (2006)

[2] Consejo de Seguridad Nuclear (Nuclear Safety Council). Resolución por la que se aprueba la apreciación favorablemente del diseño genérico propuesto por ENRESA del Diseño genérico del Almacén Temporal Centralizado (ATC) de Combustible Gastado y residuos de Alta Actividad (Decision approving the generic design proposed by ENRESA for the centralised storage facility -ATC- for spent fuel and high-level waste). www. csn. es. July 2006. (2006)

[3] Ministerio de Industria, Turismo y Comercio. Resolución del Secretario de Estado de Energía de 23 de diciembre de 2009 sobre convocatoria de municipios candidatos para albergar el almacén centralizado de combustible gastado (Decision dated december 23, 2009, from the State Secretary for Energy, calling for candidate municipalities to host the centralised storage facility for spent fuel). BOE (Official Journal). 29 December, 2009. (2009)

[4] P. Zuloaga. Spent Nuclear Fuel Management in Spain. IAEA. International Conference on Spent Fuel from Nuclear Power Reactors. 31 May - 4 June 2010 Vienna, Austria (2010)

[5] C. Andrade, M. Castellote, I. Martinez, P. Zuloaga, M. Navarro, M. Ordóñez. Concrete behaviour in engineered barriers for low and medium level radioactive waste repository: example of El Cabril, Cordoba, Spain. 6th International Congress Global Construction: Ultimate Concrete Opportunities. Dundalk, UK. (2005)

[6] K. Geelhood, C. Beyer, W. Luscher. New release of fuel performance codes, FRAPCON-3.4 and FRAPTRAN-1.4, TOPFUEL 2009, Paris, France. Paper 2067. (2009)

[7] USNRC. Spent Fuel Project Office. Interim Staff Guidance - 11, Revision 3. Cladding considerations for the transportation and storage of spent fuel. (2003)

[8] A.B. Johnson Jr, E.R. Gilbert. Technical basis for storage of Zircaloy-clad spent fuel in inert gases, PNL-4835. Pacific National Laboratory (1984)

[9] P. Zuloaga, C. Andrade, J. Rodríguez, M. García, J. Palacio. Electrochemical techniques to detect corrosion in concrete structures in nuclear installations. OECD-NEA Workshop on the Instrumentation and Monitoring of Concrete Structures. Brussels, 22-23 March (2000)

[10] C. Andrade, J. Rodriguez, F. Jimenez, J. Palacio, P. Zuloaga. Embedded sensors for concrete structures instrumentation. OECD-NEA Workshop on Instrumentation and Monitoring of Concrete Structures Brussels (Belgium). (2000)

[11] C. Andrade, I. Martínez, M. Castellote, P. Zuloaga. Some principles of service life calculation of reinforcements and in situ corrosion monitoring by sensors in the radioactive waste containers of El Cabril disposal (Spain). Journal of Nuclear Materials 358 82-95 (2006) 